4. T. Otten, T. Darbre, S. Cosnier, L. M. Abrantes, J. P. Correia and R. Keese, Helvetica Chimica

5. Acta.81 (1988) 1117. J. Bedioul, M. Voisin, J. Devynck and C. Bied-Charreton, J. Electroanal. Chem., 297 (1991) 257.

6. O. El Mouahid, C. Coutanceau, E. M. Belgsir, P. Crouigneau, J. M. Léger and C. Lamy, J. Electroanal. Chem., 426 (1997) 117.

7. O. El Mouahid, A. Rakotondrainibe, P. Crouigneau, J. M. Léger, C. Lamy, J. Electroanal. Chem., 455 (1998) 209.

8. S. Lj. Gojkovic, S. Gupta, R. F. Savinell, J. Electroanal. Chem., 462 (1999) 63.

9. G. Zheng, M. Stradiotto, L. Li, J. Electroanal. Chem., 453 (1998) 79.

10. B. Duong, R. Arechabaleta and N. J. Tao, J. Electroanal. Chem., 447 (1998) 63.

11. S. Cosnier, A. Walter, F-P. Montforts, J. Porphyrins Phtalocyanines, 2 (1998) 39.

12. L. M. Abrantes, J. P. Correia, R. Fraga, T. Darbre, R. Keese, Portugaliae Electrochim. Acta, 16 (1998) 93.

Received, June 6, 1999

Revised, December 14, 1999

\section{CONVERSION COATINGS FOR ALUMINIUM METAL MATRIX} COMPOSITES

C.M. Rangel, T.I. Paiva

Instituto Nacional de Engenharia e Tecnologia Industrial IMP/DM - Electroquímica de Materiais Estrada do Paço do Lumiar, 22

\title{
Abstract
}

$\mathrm{Al} 6061$ powder and $\mathrm{F} 800$ grade $\mathrm{SiC}$ particles $(\mathrm{SiCp})$ were used as raw materials for the preparation of metal matrix composites (MMC), via a powder metallurgy route (PM), with $0 \%$ to 20 wt $\%$ of $\mathrm{SiCp}$, the reinforcement material. Corrosion studies revealed a linear dependency of the pitting potential (Ep) with the logarithm of the concentration of $\mathrm{NaCl}$ with a slope of $\sim-90 \mathrm{mV} /$ decade, but there was no significant difference in the Ep values of the composite materials as a function of the concentration of reinforcement. Corrosion protection of PM Al SiC alloys was achieved by favouring the formation of a Ce/Mo-based conversion coating on the surface without the use of external polarisation. Pitting potentials were assessed in a $0.1 \mathrm{M} \mathrm{NaCl}$ solution after treatment. No increase in current density was evident for samples treated at $\mathrm{pH} 4.4$ followed by post-treatment at $60^{\circ} \mathrm{C}$ for one hour, when polarised up to $0 \mathrm{mV}$ (SCE). The role of $\mathrm{Ce}$ and $\mathrm{Mo}$ as inhibitors is analysed and discussed in terms of the protective character of the produced cerium-molybdenum conversion coatings.

\section{Introduction}

For aluminium metal matrix composites (MMC's), it is recognised that as a result of the incorporation of reinforcement, an increase in the corrosion of the matrix occurs with preferential attack at the reinforcement/ matrix interface. Pores, crevices, second phases and interfacial reaction products have a significant contribution to the corrosion susceptibility [1-15].

Since MMC's make attractive materials for a wide range of applications due to properties such as high strength and stiffness, lightness and low coefficient of thermal 
expansion, various aspects of their corrosion protection have been investigated from conventional anodising to new alternatives treatments for conversion coatings [16-21].

The present work reports on the corrosion behaviour of PM Al 6061 MMC's in aqueous sodium chloride solutions and the protective character of a Ce/Mo conversion coating treatment implemented without the aid of external polarisation.

\section{Experimental}

Discs of $0.55 \mathrm{~cm}^{2}$ diameter of the composite material were used as working electrodes. The composites were produced by a powder metallurgy (PM) route from raw materials: Al 6061 powder $(27 \mu \mathrm{m})$ and $\mathrm{F} 800$ grade $10 \mu \mathrm{m} \mathrm{SiC} \mathrm{particles} \mathrm{(} \mathrm{SiCp})(\mathrm{PM})$, with compositions including 10 to $20 \mathrm{wt} \%$ of SiCp. Preparation of composites was done by the Materials Processing Division at INETI according to procedure indicated elsewhere [21]. A wrought alloy was also used in this study, for comparison.

The electrodes were polished to a $1 \mu \mathrm{m}$ finish and rinsed with de-ionised water and ethanol. Solutions were prepared with distilled water and ANALAR reagents.

A conventional electrochemical cell was used with a Lugging Harber capillary as a bridge to an external saturated calomel electrode (SCE) and a platinum counterelectrode.

Voltammograms were conducted using an EG\&G Potentiostat/Galvanostat Model 273A for $\mathrm{NaCl}$ concentrations from $0.05 \mathrm{M}$ to $0.6 \mathrm{M}$ at a scan rate of $5 \mathrm{mVs}^{-1}$.

Cerium/molybdate based conversion layers were produced in buffered solutions containing $6.7 \mathrm{ppm}$ molybdate as $\mathrm{Na}_{2} \mathrm{MoO}_{4}, \mathrm{Ce}\left(\mathrm{NO}_{3}\right)_{3}$ (2 to 20ppm) as well as $0.05 \mathrm{M}$ acetic/sodium acetate. Sodium fluoride was added to a concentration of $0.1 \mathrm{M}$ after immersion of the specimen, in order to remove the air formed film allowing an efficient conversion coating formation. All the solutions were exposed to the open air and the temperature was $20 \pm 2^{\circ} \mathrm{C}$, unless indicated otherwise.

Potential-times curves were registered in a Data Logger, Model 3531-D, from Solartron Schlumberger. After the formation of the conversion coating, samples were treated in an air furnace at $60^{\circ} \mathrm{C}$ during 1 hour. Afterwards, pitting potentials were assessed in a $0.1 \mathrm{M} \mathrm{NaCl}$ solution.

\section{Results}

Cyclic voltammograms were conducted for the composite materials, PM Al 6061 with $0,10,15,20 \mathrm{wt} \%$ in $\mathrm{SiCp}$, in solutions with concentrations varying from $0.05 \mathrm{M}$ to 0.6 $\mathrm{M}$ of sodium chloride. A typical curve is shown in figure 1a). Results indicated no significant variation of the pitting potential (Ep) for the alloys produced by powder metallurgy, even though the indicated tendency, as pitting potentials is concerned, was one of more susceptibility when particles of SiCp are present.

The protection potential, (Epp), was also estimated and $\Delta$ (Ep-Epp) values used to assess repassivation behaviour. Values varied from $\sim 120$ to $210 \mathrm{mV}$ with the highest values corresponding to the $20 \mathrm{wt} \% \mathrm{SiCp}$ alloy. The $\Delta$ (Ep-Epp) value obtained, in the same conditions, for a wrought alloy of the same composition (6061) was $80 \mathrm{mV}$ with the pitting potential slightly more cathodic than for the PM alloys.

The cathodic branch of the curves did not suggest significant galvanic interaction between $\mathrm{SiC}$ particles and the matrix.

Figure 1b) shows the variation of Ep with the logarithm of sodium chloride concentration in solution for PM $6061 \mathrm{Al} \mathrm{SiC}$ alloys, exhibiting a linear relationship $(\sim-90 \mathrm{mV} /$ decade) and showing, overall the range of studied concentrations, no significant difference in the Ep values for the composite alloys. Values were slightly more noble than those obtained for the wrought alloy.

Surface morphology examination of exposed surfaces, after breakdown induced by polarisation in $\mathrm{NaCl}$ solutions, for MMC's and reference materials, showed smaller pits for the reinforced alloys. This was confirmed by quantitative metallography. Results are presented elsewhere [21]. Examination of cross sections of the samples revealed shallower pits for the composite alloys.

Corrosion protection of PM $6061 \mathrm{Al} \mathrm{SiC}$ alloys was attempted by favouring the formation of a Ce/Mo-based conversion coating on the surface without the aid of 


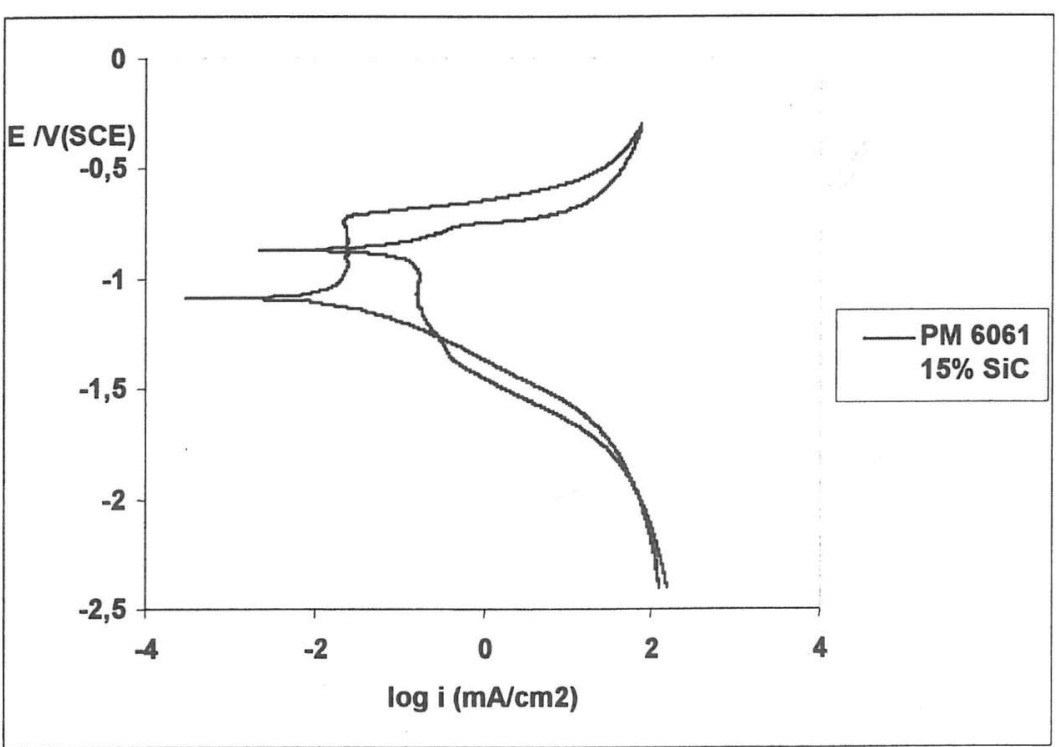

(a)

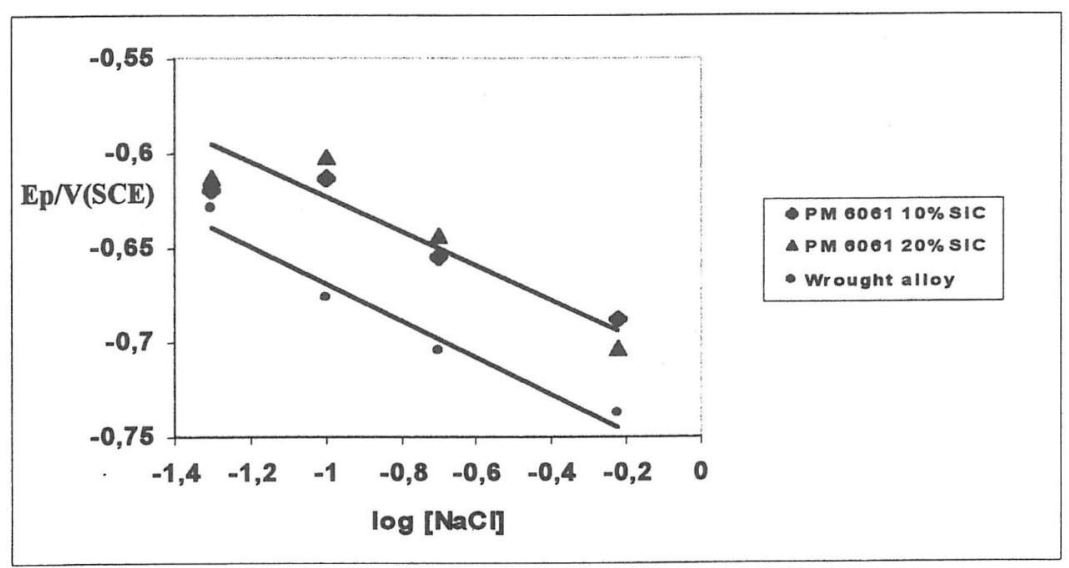

(b)

Fig.1 Polarisation characteristics for PM 6061 Al SiC composites in sodium chloride solutions.

Cyclic voltammogram for a $15 \% \mathrm{SiCp}$ alloy in $0.05 \mathrm{M} \mathrm{NaCl}$ solution (a).

The pitting potential (Ep) as a function of the concentration of $\mathrm{NaCl}$ (b). Comparison with values obtained for a 6061 wrought alloy under the same Comparison with values obtained for a
experimental conditions. Scan rate $5 \mathrm{mVs}^{-1}$. external polarisation. The potential vs time profile was followed during the conversion coating formation at different solution $\mathrm{pH}$ values within the range from 4 to 5 . After an initial sharp fall of the potential due to the dissolution of the air formed film, promoted by the addition of $\mathrm{NaF}$, the formation of a protective layer was indicated by the rise in potential to $\sim-0.5 \mathrm{~V}(\mathrm{SCE})$. The coating was fully-grown in 60 seconds as evident in figure 2. Protective films were formed within a narrow range of treatment solution $\mathrm{pH}$.

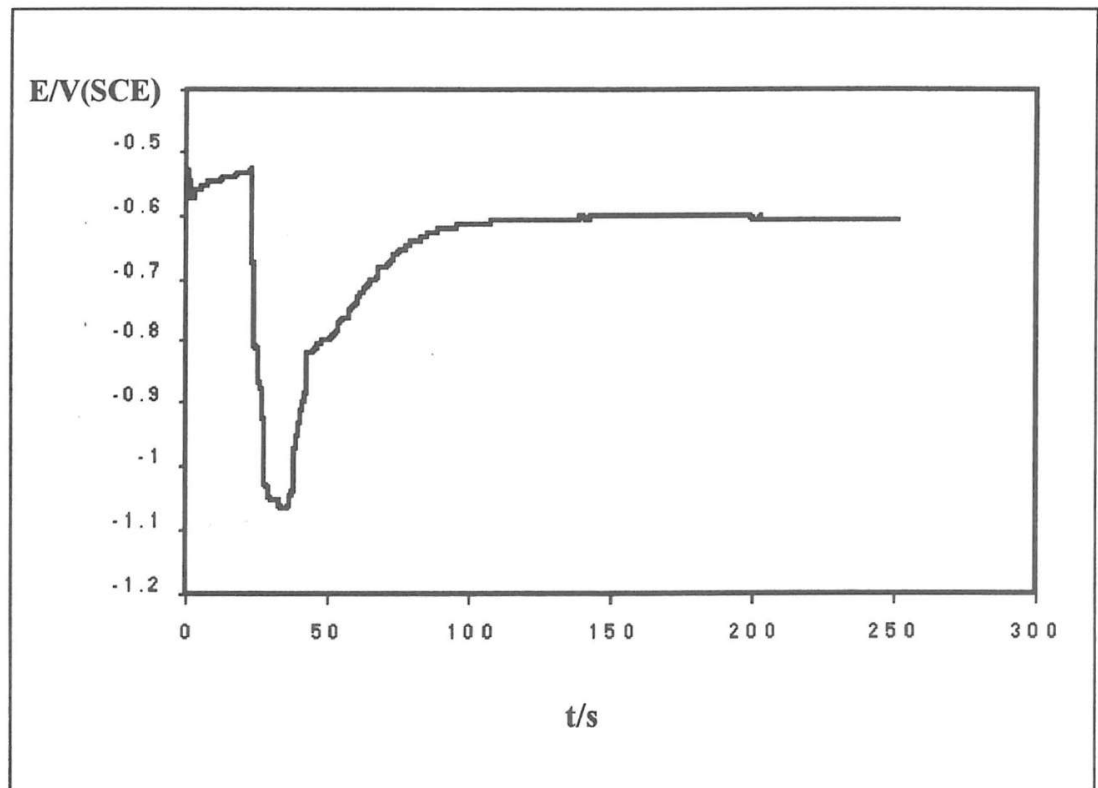

Fig.2 Potential vs time data for the immersion of PM6061 $\mathrm{SiC}$ alloys in molybdate/ceriate/fluoride solutions, at room temperature, $\mathrm{pH}$ 4.4.

An ennoblement of the pitting potentials is evident as well as a change of slope of the current density-potential curve - when compared with the curves for the alloy without the conversion coating or in the presence of a conversion coating produced using a molybdate solution alone.

Figure 3a) shows polarisation curves for PM Al $606115 \% \mathrm{SiC}$ alloy in a $0.1 \mathrm{M} \mathrm{NaCl}$ after treatment with a mixture of Mo and Ce salts. When a post-treatment was given to the sample by baking it at $60^{\circ} \mathrm{C}$, in an air furnace, during 1 hour, a remarkable decrease 
of the current density was appreciated. Overall the studied range of potentials the current was very low so that the polarisation curves are practically superimposed to the $\mathrm{X}$ - axes in the graph. Polarisation proceeded up to $0 \mathrm{mV}$ without exhibiting a breakdown potential, figure $3 \mathrm{~b}$ ). When examining in detail the latter figure, fluctuations in the current were observed when polarising in the direction of more noble potentials due to the onset of metastable pitting. When the scanning of the potential was reversed, repassivation was evident with current densities dropping to zero without apparent fluctuations.

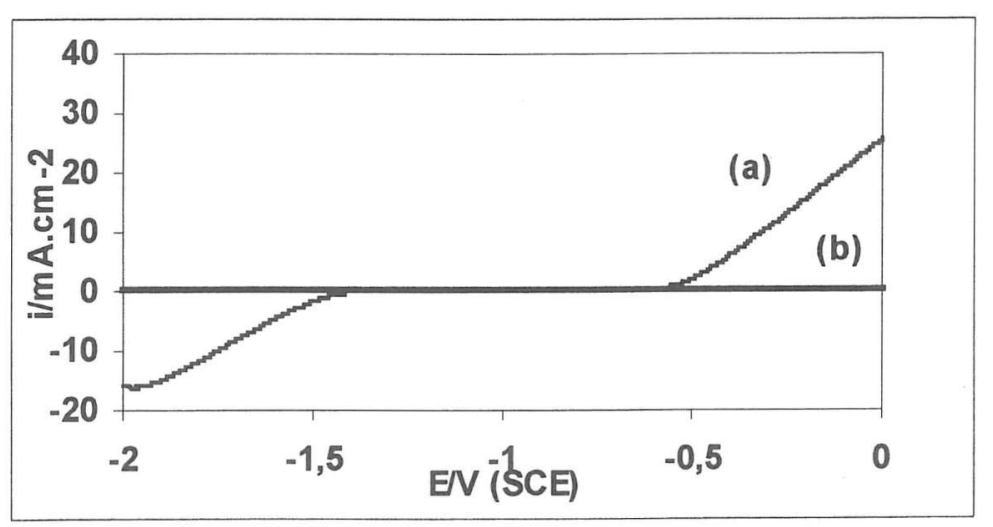

Fig.3 Cyclic polarisation curves for PM $6061 \mathrm{Al} 15 \mathrm{wt} \% \mathrm{SiC}$ alloy in $0.1 \mathrm{M} \mathrm{NaC}$ after the formation of the $\mathrm{Ce} / \mathrm{M}$ o conversion coating:

without heat treatment (a) with heat treatment(b)

Ce and Mo were detected by EDAX and RBS. Surface morphology and composition of the obtained films will be reported elsewhere[25].

\section{Discussion}

In order to reduce the use of chromate based surface treatments for $\mathrm{Al}$ alloys, a number of alternative processes are being research for acceptable corrosion resistance and a base for subsequent treatments, such as painting. Molybdates are obvious replacements for chromate conversion coatings with analogies in the participation for electroreduction, producing compounds that are less soluble in acid than normal alumina and blocking the cathodic reaction.
Conversion coatings based on Mo alone, using a buffer and a complexant, did not produced a corrosion resistance coating on the composite alloy, in the experimental conditions used in this work. Success of chromate conversion coatings relies on the redox behaviour of $\mathrm{Cr}^{+6}$, obviously $\mathrm{Mo}^{+6}$ has less oxidising power. Corrosion inhibition is then thought to be aided with the addition of $\mathrm{Ce}$ to the Mo bath. As a result the formation of a cerium rich insoluble film is expected to form at cathodic sites as a response to an increase in the local $\mathrm{pH}$.

Fluoride ions were added due to their ability of reacting with the air formed alumina film forming strong co-ordination soluble complexes with $\mathrm{Al}$ cations (equation (1)). The metallic surface is then capable of forming effectively the conversion coating.

$$
\mathrm{Al}_{2} \mathrm{O}_{3}+12 \mathrm{~F}^{-}+3 \mathrm{H}_{2} \mathrm{O} \Rightarrow 2 \mathrm{AlF}_{6}^{-3}+6 \mathrm{OH}^{-}
$$

The Pourbaix diagram indicates, for the solution $\mathrm{pH}$ used in this work, equations (2) and (3) for $\mathrm{Al}$ and $\mathrm{Mo}$, and that $\mathrm{Ce}$ is in the trivalent state [22] (see figure 4)

It is to be noticed that on metal surfaces where the oxygen reduction is via a $2 \mathrm{e}$ pathway, $\mathrm{Ce}^{+3}$ can be oxydised to $\mathrm{Ce}^{+4}$ by $\mathrm{H}_{2} \mathrm{O}_{2}$, intermediate in the oxygen reduction reaction (reactions (4) and (5)) [23,24]. As the $\mathrm{pH}$ increases locally, further reaction with hydroxide ions can lead to the production of cerium oxide (equation 6).

$$
\begin{aligned}
& 2 \mathrm{Al} \Rightarrow 2 \mathrm{Al}^{+3}+6 \mathrm{e}- \\
& \mathrm{Mo}^{+6}+2 \mathrm{e}^{-} \Rightarrow \mathrm{Mo}^{+4} \\
& \mathrm{O}_{2}+2 \mathrm{H}_{2} \mathrm{O}+2 \mathrm{e}^{-} \Rightarrow \mathrm{H}_{2} \mathrm{O}_{2}+2 \mathrm{OH}^{-} \\
& 2 \mathrm{Ce}^{+3}+2 \mathrm{OH}^{-}+\mathrm{H}_{2} \mathrm{O}_{2} \Rightarrow 2 \mathrm{Ce}(\mathrm{OH})_{2}{ }^{2+} \\
& 2 \mathrm{Ce}(\mathrm{OH})_{2}{ }^{2+}+4 \mathrm{OH}^{-} \Rightarrow 2 \mathrm{CeO}_{2}+4 \mathrm{H}_{2} \mathrm{O} \\
& 2 \mathrm{Ce}^{+3}+4 \mathrm{OH}^{-}+\mathrm{O}_{2}+2 \mathrm{e}^{-} \Rightarrow 2 \mathrm{CeO}_{2}+2 \mathrm{H}_{2} \mathrm{O}
\end{aligned}
$$


In this way the formation of a cerium and molybdenum oxide can be justified The presence of Mo and Ce have been detected by EDAX and RBS. Results will be reported elsewhere [25]

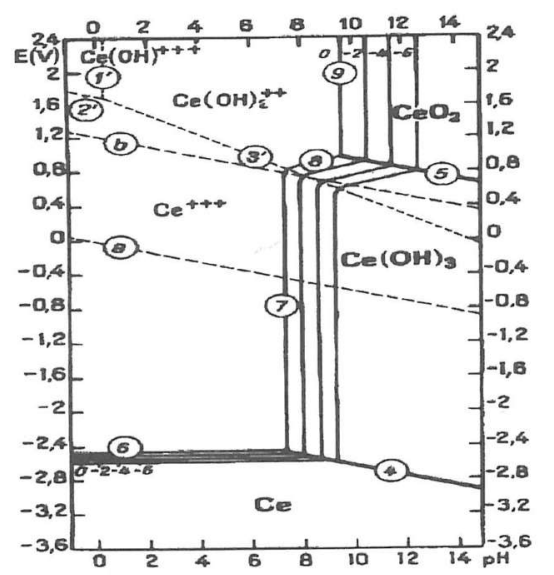

Fig 4. Pourbaix diagram for the system $\mathrm{Ce} / \mathrm{H}_{2} \mathrm{O}[22]$

\section{Conclusions}

- The pitting potential, Ep, was not considered meaningful for the assessment of the susceptibility to pitting in MMC's. Quantitative metallography indicated that the numbers of pits increased with the amount of reinforcement, furthermore, the number of larger pits is diminished.

- A treatment that combined Ce and Mo was introduced as a corrosion protection measure to lower the susceptibility to pitting corrosion of PM $6061 \mathrm{Al} \mathrm{SiC}$ alloys with excellent results.

\section{Acknowledgements}

Acknowledgements are due to Eng. M.H. Carvalho for provision of material

\section{References}

[1]- A.Turnbull, Brit. Corros. J., 27, 27(1992)

[2]- D. M. Aylor and P.J.Moran, J. Electrochem. Soc., 132,1277 (1985).
[3]- P.P.TrzasKoma, E. Mc. Cafferty and C.R. Crowe, J. Electrochem. Soc., 130, 1804(1983).

[4]- M. Kending, S. Jean Jaquet and M. Mahoney, Corrosion 88, Paper $\mathrm{n}^{\circ} 383$, Cervantes Convention Center/St. Louis, Missouri, 1988.

[5]- L. H Hihara, R. M. Latansion, Corrosion, 47, 335 (1991)

[6]- C.Friend, C.Naish, T. M.O'Brien, G. Sample, Proceedings ECCM-Stuttgard, p. 307, 1990

[7]- R. P. Tischer, W. L. Winterbotton, H.S. Coroblowa, Corros. Sci., 26, 377(1986).

[8]- S.Colleman, V. Scott, B. McEnaney, J. Mater. Sci., 29, 2826 (1994).

[9]- F. Mansfeld, S. L. Jean Jaquet, Corros. Sci., 26, 727 (1986).

[10]- F. Mansfeld, S. Lin Kim, H. Shih, Corrosion, 45, 615 (1989).

[11]- F. Mansfeld, S. Lin Kim, H. Shih, J. Electrochem. Soc., 137, 78 (1990)

[12]- A.J. Griffiths, A. Turnbull, Corros. Sci., 36, 23 (1994).

[13]- A. J. Trowsdale, B. Noble, S.J. Harris, I.S.R Gibbins, G.E. Thompson, G.C. Wood, Corros. Sci., 38, 177 (1996).

[14]- R. Deuis, L. Green, C. Subramanian, J. Mater. Sci. Letters, 16, 440 (1997)

[15]- J.E. Castle, L.Sun, H.Yan, Corros. Sci., 36, 1093 (1994).

[16]- Hou Jiangyuan, D.D.L Chung., J. of Mater. Sci., 32, 3116 (1997)

[17]- M. Shahaid, J. of Mater. Sci., 32, 3775 (1997).

[18]- Hughes A. E., Gorman J. D., Paterson P. J. K., Corros. Sci., 38, 1957(1996),

[19]- J. D. Gorman, S. T. Johnson, P. N. Johnson, P. J. K. Paterson, A. E. Hughes, Corros. Sci., 38, 1977 (1996)

[20]- C. Chen, F. Mansfeld, Corros. Sci., 39, 1075 (1997).

[21]- C.M. Rangel, T.I. Paiva, EUROCORR 98, Utrecht, 1998.

[22]- M. Pourbaix, "Atlas of Electrochemical Equilibria in Aqueous solution", NACE, Houston, TX (1974).

[23]- J.O'M. Bockris, and S.U,M, Khan, "Surface Electrochemistry", Plenum Press, New York (1993).

[24]- A .J. Aldykiewicz, Jr., A. J. Davenport, H. S. Isaacs, J. Electrochem. Soc., 143, 147(1996).

[25]- C.M. Rangel, T.I. Paiva, to be submitted to Corros.Sci., 2000 